\title{
DISTRIBUSI SPASIAL DAN TEMPORAL IKAN ENDEMIK RAINBOW SELEBENSIS (Telmatherina celebensis Boulenger) DI DANAU TOWUTI, SULAWESI SELATAN
}

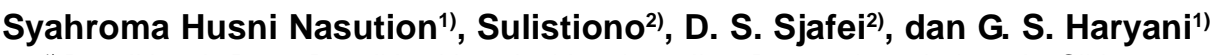 \\ 1) Peneliti pada Pusat Penelitian Limnologi-Lembaga IImu Pengetahuan Indonesia, Cibinong \\ 2) Peneliti pada Fakultas Perikanan dan IImu Kelautan-Institut Pertanian Bogor, Bogor
}

Teregristrasi I tanggal: 22 September 2006; Diterima setelah perbaikan tanggal: 22 Mei 2007; Disetujui terbit tanggal: 8 Juni 2007

\begin{abstract}
ABSTRAK
Rainbow selebensis (Telmatherina celebensis) adalah salah satu jenis ikan endemik di Danau Towuti. Ikan tersebut memiliki warna tubuh yang indah dan berpotensi sebagai ikan hias air tawar yang bernilai ekonomis. Dikhawatirkan akan terjadi penurunan populasi ikan tersebut di alam akibat perubahan lingkungan dan penangkapan ikan yang intensif. Penurunan kualitas lingkungan tersebut secara tidak langsung berkaitan dengan penebangan hutan. Penelitian ini bertujuan untuk mengetahui distribusi spasial dan temporal ikan Rainbow Selebensis. Penelitian dilakukan di perairan Danau Towuti dari bulan Maret 2002 sampai dengan April 2003. Ikan ditangkap menggunakan jaring insang eksperimental (experimental gill net) dengan 4 ukuran mata jaring yaitu $3 / 4,1,1 \frac{1}{4}$, dan $1 \frac{1}{2}$ inci di 4 stasiun. Hasil penelitian menunjukkan bahwa ikan Rainbow selebensis berdistribusi luas di perairan Danau Towuti mulai dari wilayah litoral sampai dengan ke tengah danau. Jumlah ikan yang diperoleh lebih banyak dan ukuran ikan juga lebih bervariasi di stasiun yang terdapat tanaman air (stasiun I dan IV) dibandingkan di stasiun yang tidak terdapat tanaman air (stasiun II dan III). Distribusi ikan secara spasial dipengaruhi oleh kedalaman air dan tanaman air, sedangkan secara temporal dipengaruhi oleh ketinggian muka air, oksigen terlarut, dan $\mathrm{pH}$. Puncak kelimpahan ikan ini ditemukan pada bulan Nopember.
\end{abstract}

KATAKUNCI: distribusi spasial dan temporal, Telmatherina celebensis, ikan endemik, Danau Towuti

ABSTRACT: Spatial and temporal distribution of rainbow selebensis endemic fish (Telmatherina celebensis Boulenger) in Lake Towuti. By: Syahroma Husni Nasution, Sulistiono, D. S. Sjafei, and G. S. Haryani

Rainbow selebensis (Telmatherina celebensis) is an endemic species in Lake Towuti. This species has excellent body color, which is commercialized as ornamental fishes. Concerning will be decress fish population due to change of environment and intensive fishing. Degradation of the environmental quality indirectly related the deforestation. The aim of this research is to obtain information on spatial and temporal distribution of Rainbow Selebensis in Lake Towuti on March 2002 until April 2003. The fish was captured with experimental gill net mesh size 0.75; 1; 1.25; and 1.5 inches at four stations. The result shows that Rainbow Celebensis has wide distribution in Lake Towuti from litoral zone until the middle of lake. At station where there are aquatic plant (station I and IV), the number and size of the fish were high and various compared to station where there were aquatic plant (station II and III). Spatial distribution of Rainbow selebensis was influenced by depth of water and existence of aquatic plant, while temporal distribution was influenced by water level, dissolved oxygen, and $\mathrm{pH}$. The peak season abundance of the fish was in November.

KEYWORDS: temporal and spatial distribution, Telmatherina celebensis, endemic fish, Lake Towuti

\section{PENDAHULUAN}

Rainbow selebensis (Telmatherina celebensis Boulenger) adalah salah satu jenis ikan endemik yang terdapat di Danau Towuti. Ada 16 jenis ikan dari genus Telmatherina yang ada, semua termasuk jenis ikan endemik (Kottelat et al., 1993). T. celebensis memiliki warna tubuh yang indah, pada badan ikan jantan berwarna kuning kecoklatan di bagian dorsal dan terdapat 3 atau lebih pita vertikal yang terlihat lebih kontras dibandingkan ikan betina. Oleh karena itu, ikan tersebut berpotensi sebagai ikan hias air tawar yang bernilai ekonomis. Untuk itu, ikan ini perlu dilindungi dari ancaman kepunahan karena populasi ikan tersebut di alam dikhawatirkan akan mengalami penurunan.

Penurunan populasi diperkirakan akibat perubahan lingkungan (makanan, habitat, dan kualitas air) dan penangkapan ikan yang intensif. Penurunan kualitas lingkungan tersebut secara tidak langsung berkaitan dengan ada penebangan hutan.

Kosrespondensi penulis: 
Danau Towuti adalah salah satu danau yang terdapat di wilayah Kompleks Malili selain Danau Matano, Mahalona, Lantoa, dan Masapi. Ketiga danau yaitu Matano, Mahalona, dan Towuti berterap (cascade), pada bagian hulu Danau Matano, bagian tengah Danau Mahalona, dan pada bagian hilir adalah Danau Towuti. Danau Towuti dan Danau Mahalona sebagai tempat hidup ikan ini termasuk kawasan taman wisata alam berdasarkan pada keputusan Mentan No.274/Kpts/Um/ 1979. Danau Towuti mempunyai luas $560 \mathrm{~km}^{2}$, kedalaman maksimum 203 m, ketinggian dari permukaan laut 293 $\mathrm{m}$, dan transparansi air sedalam $22 \mathrm{~m}$ (Fernando dalam Haffner et al., 2001).

Distribusi spasial ikan atau keberadaan ikan berdasarkan pada tempat (ruang) di suatu perairan dan distribusi temporal ikan (berdasarkan pada waktu kapan ikan berada) dibatasi oleh berbagai faktor seperti tingkah laku memilih habitat, kebutuhan fisiologis, maupun interaksi dengan lingkungan. Distribusi ikan diduga tidak merata di setiap stasiun perairan Danau Towuti. Demikian pula, dengan ukuran, di mana pada tempat dan waktu tertentu ukuran besar, sedang yang lain ukuran kecil. Distribusi yang demikian akan memberikan gambaran perkembangan ikan terhadap perubahan lingkungan.
Berdasarkan pada permasalahan tersebut, untuk melindungi populasi ikan Rainbow selebensis tetap tinggi dan berkelanjutan, diperlukan pengetahuan tentang distribusi spasial dan temporal ikan tersebut. Informasi distribusi ikan tersebut dapat menggambarkan kondisi populasi ikan tersebut yang dapat digunakan sebagai informasi dasar untuk mendukung usaha konservasi. Informasi yang diperoleh diharapkan menjadi landasan dalam rangka merumuskan kebijakan pengelolaan sumber daya ikan di Danau Towuti.

\section{BAHAN DAN METODE}

Penelitian dilakukan di perairan Danau Towuti Sulawesi Selatan setiap 2 bulan selama 14 bulan dari bulan Maret 2002 sampai dengan April 2003. Penentuan stasiun penelitian berdasarkan pada pertimbangan bahwa 1) contoh ikan yang diperoleh akan mewakili ikan Rainbow selebensis yang ada di Danau Towuti; 2) habitat sesuai bagi ikan tersebut; dan 3) efisiensi operasional pelaksanaan. Berdasarkan pada hal tersebut ditetapkan 4 stasiun penelitian di Danau Towuti (Gambar 1).

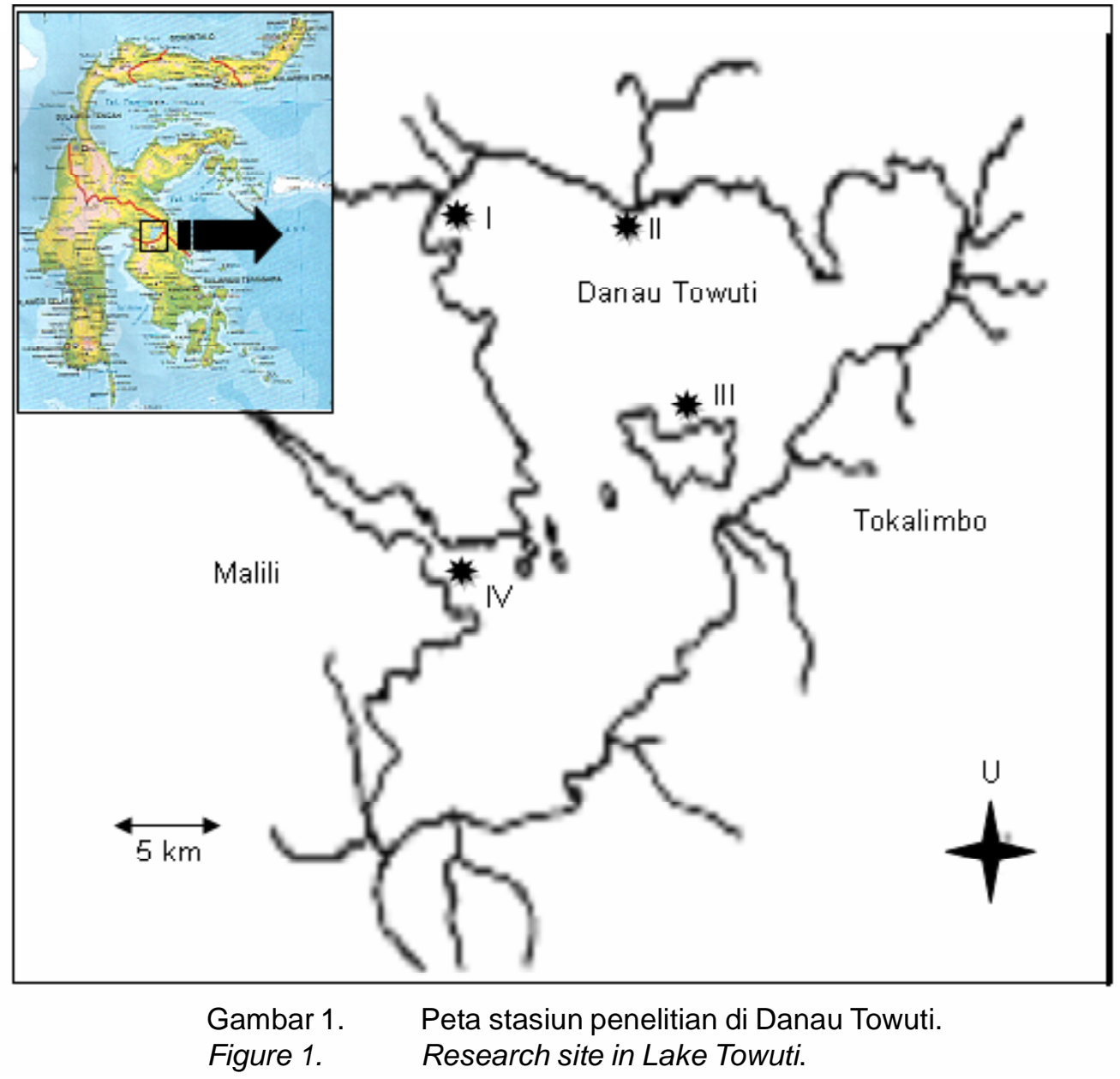


Stasiun I: terletak di daerah yang terdapat tanaman air dengan kedalaman air 1 sampai dengan $3 \mathrm{~m}$ (Tanjung Bakara dekat Sawmill). Koordinat: S 0240’47,1"; E $121^{\circ} 25^{\prime} 04,0 "$.

Stasiun II: terletak di daerah yang tidak terdapat tanaman air dengan kedalaman air 1 sampai dengan 5 $\mathrm{m}$ (inlet Danau Towuti yang berasal dari Sungai Tominanga). Koordinat: S 02³9’43,4"; E 121 ${ }^{\circ} 32^{\prime} 46,0^{\prime \prime}$.

Stasiun III: terletak di daerah yang tidak terdapat tanaman air dengan kedalaman air lebih dari $10 \mathrm{~m}$ (Pulau Loeha). Koordinat: S 0244'33,9"; E 121³4'44,6".

Stasiun IV: terletak di daerah yang terdapat tanaman air dengan kedalaman air 1 sampai dengan $3 \mathrm{~m}$ (outlet Danau Towuti yang mengalir ke Sungai Hola-hola). Koordinat: S 0247’35,1"; E 121²4'21,1".

Contoh ikan diperoleh dari hasil penangkapan menggunakan jaring insang eksperimental dengan 4 ukuran mata jaring yaitu $3 / 4,1,1 \frac{1}{4}$, dan 11/2 inci. Satu unit alat tangkap tersebut berukuran panjang masingmasing $50 \mathrm{~m}$ dan tinggi $2 \mathrm{~m}$. Jaring dilengkapi pelampung pada bagian atas dan pemberat di bagian bawah. Jaring dioperasikan dengan cara dibentangkan secara tegak lurus dengan garis pantai di setiap stasiun yang dipasang di kolom air bagian atas.

Hasil tangkapan dari masing-masing stasiun pengamatan dipisahkan menurut ukuran dan jenis kelamin. Dihitung jumlah dan ukuran ikan per penarikan alat tangkap selama 15 jam dari pukul 16.00 sampai dengan 07.00 setiap 2 bulan. Contoh ikan diawetkan dengan formalin $4 \%$ selanjutnya direndam dalam alkohol $70 \%$. Contoh ikan diukur panjang dan bobot masingmasing menggunakan jangka sorong dengan ketelitian $1 \mathrm{~mm}$ dan timbangan dengan ketelitian 0,01 g.

Pengukuran kualitas air dilakukan di setiap stasiun sebelum penangkapan ikan dilakukan. Pengambilan air dilakukan secara horisontal dalam badan air (sampai dengan $50 \mathrm{~cm}$ di bawah permukaan air) menggunakan kemmerer water sampler. Parameter yang diamati meliputi suhu, kekeruhan, alkalinitas, $\mathrm{pH}$, dan oksigen terlarut masing-masing diukur menggunakan termometer, Turbidity scale Model DR EL/1, titrasi asam basa (APHAAWWA-WEF, 1998), $\mathrm{pH}$ meter, dan metode Winkler (APHA-AWWA-WEF, 1998), sedangkan parameter curah hujan dan tinggi muka air berupa data sekunder yang diperoleh dari PT. Inco.

Distribusi kelimpahan ikan antar stasiun atau habitat dan antar waktu atau musim, dianalisis secara non parametrik menggunakan Mann-Whitney Test (Steel \& Torrie, 1981) pada Paket Software Minitab. Untuk melihat parameter kualitas air yang berpengaruh terhadap kelimpahan ikan, dilakukan analisis regresi berganda pada Paket Software Minitab dengan metode yang dijelaskan oleh Steel \& Torrie (1981).

\section{HASIL DAN BAHASAN}

Distribusi spasial ikan atau keberadaan ikan berdasarkan pada tempat (ruang) di suatu perairan dan distribusi temporal ikan (berdasarkan pada waktu kapan ikan berada) dibatasi oleh berbagai faktor seperti tingkah laku memilih habitat maupun interaksi dengan lingkungan seperti suhu, kedalaman air, cahaya, pH, oksigen terlarut, makanan, dan tanaman air (Bhukaswan, 1980).

\section{Distribusi Spasial}

Ikan T. celebensis yang tertangkap berjumlah 1.179 ekor yang terdiri atas 632 ekor jantan dan 547 ekor betina. Data distribusi ikan T. celebensis antar stasiun (dikatakan dalam kelimpahan dan ukuran), disusun mulai dari stasiun dengan kelimpahan tertinggi sampai dengan terendah, masing-masing adalah stasiun I (jantan=312 dan betina=211), IV (jantan=189 dan betina=217), II (jantan=102 dan betina=99), dan III (jantan=29 dan betina=20) (Gambar 2). Ikan T. celebensis dijumpai pada semua stasiun pengamatan, bahkan Wirjoatmodjo et al., (2003), mengatakan ikan T. celebensis ditemukan pada 13 statiun dari 18 stasiun yang diamati di Danau Towuti. Hal ini, menunjukkan bahwa ikan ini berdistribusi luas di Danau Towuti mulai dari pinggiran danau sampai dengan ke tengah danau. 


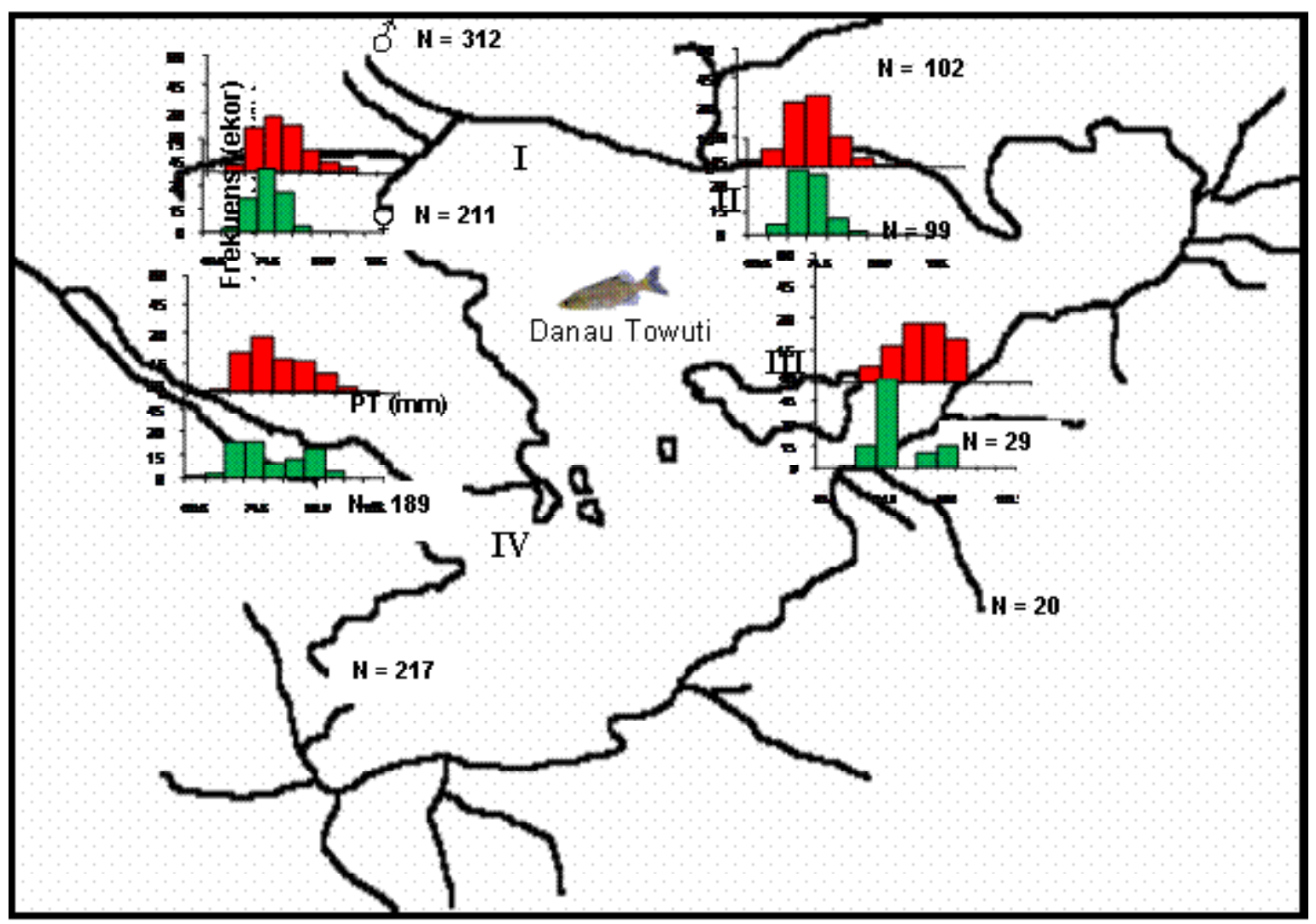

Gambar 2. Hubungan antara kelimpahan dengan distribusi ukuran ikan T. celebensis jantan dan betina pada setiap stasiun (I, II, III, dan IV).

Figure 2. Relation between fish abundance and size distribution of male and female T. celebensis at each station (I, II, III, dan IV).

Sebaran ukuran panjang ikan T. celebensis di seluruh stasiun dianalisis untuk mengetahui apakah kelimpahan ikan yang terdapat di stasiun tersebut sama dengan stasiun lain. Berdasarkan pada uji non parametrik MannWhitney pada Tabel 1 menunjukkan ada perbedaan kelimpahan ikan yang tertangkap. Perbedaan kelimpahan ikan terutama terlihat jelas di stasiun III di mana jumlah ikan yang tertangkap sangat sedikit dibandingkan stasiun lain. Hal ini, disebabkan kondisi fisik stasiun tersebut.

Secara fisik, stasiun III (Pulau Loeha) sangat berbeda dibandingkan stasiun lain yaitu kedalaman air lebih dari $10 \mathrm{~m}$ dan tidak terdapat tanaman air (sama dengan stasiun Il yaitu daerah yang tidak terdapat tanaman air). Di stasiun I dan IV yang terdapat tanaman air kelimpahan ikan lebih tinggi dibandingkan stasiun yang tidak terdapat tanaman air. Perbedaan kelimpahan ikan antar stasiun disebabkan oleh perbedaan kedalaman dan keberadaan tanaman air yang merupakan faktor penting penunjang kehidupan ikan.

Distribusi ukuran panjang total ikan T. celebensis betina di stasiun III, memperlihatkan ada kelas ukuran 74,8 sampai dengan $79,5 \mathrm{~mm}$ yang hilang. Hal ini, diduga ada hambatan rekruitmen yang mengakibatkan ikan betina pada kelas ukuran tersebut tidak ditemukan selama pengamatan. Distribusi ukuran panjang ikan $T$. celebensis di stasiun lain (I, II, dan IV) lebih merata dibandingkan di stasiun III. Hal ini, menunjukkan stasiun III bukan merupakan habitat yang cocok bagi ikan $T$. celebensis.

Distribusi ikan dipengaruhi oleh faktor abiotik (kualitas air dan habitat) dan biotik (makanan alami dan tanaman air). Berdasarkan pada uji Mann-Whitney terhadap parameter kualitas air (suhu, $\mathrm{pH}$, turbiditas, oksigen terlarut, dan alkalinitas) antar stasiun tidak menunjukkan perbedaan yang nyata (stasiun I-II $=0,9362(\mathrm{~ns})$; stasiun $\mathrm{I}-\mathrm{III}=0,7986$ (ns); stasiun I-IV=0,5518 (ns); stasiun II$\mathrm{III}=0,8531$ (ns); stasiun II-IV=0,5820 (ns); dan stasiun IIIIV $=0,7147$ (ns). Hal ini, menandakan bahwa semua parameter di masing-masing stasiun dianggap sama. Dengan demikian, dapat dikatakan bahwa secara spasial parameter kualitas air tersebut tidak berkorelasi terhadap kelimpahan ikan. Perbedaan kelimpahan ikan secara spasial diduga karena faktor lain misal tipe habitat dan ada tanaman air. 
Tabel 1. Uji perbedaan kelimpahan ikan T. celebensis jantan dan betina pada setiap stasiun Table 1. Test difference of male and female T. celebensis abundance in each station

\begin{tabular}{ccccccc}
\hline & \multicolumn{3}{c}{ Jantan/Male } & \multicolumn{3}{c}{ Betina/Female } \\
\cline { 2 - 7 } & II & III & IV & II & III & IV \\
\hline I & $0,0259(\mathrm{~s})$ & $0,0053(\mathrm{~s})$ & $0,3907(\mathrm{~ns})$ & $0,0949(\mathrm{~ns})$ & $0,0080(\mathrm{~s})$ & $0,9427(\mathrm{~ns})$ \\
II & & $0,0373(\mathrm{~s})$ & $0,1747(\mathrm{~ns})$ & & $0,0367(\mathrm{~s})$ & $0,0856(\mathrm{~ns})$ \\
III & & & $0,0081(\mathrm{~s})$ & & & $0,0131(\mathrm{~s})$ \\
\hline
\end{tabular}

Keterangan/Remarks: $\quad \propto>0,0500=$ ns (tidak berbeda); $\propto<0,0500=\mathrm{s}$ (berbeda); I = Tanjung Bakara; II = inlet Danau Towuti dari Sungai Tominanga; III = Pulau Loeha; IV = outlet Danau Towuti ke Sungai Hola-hola

Tipe habitat masing-masing stasiun menunjukkan perbedaan, terutama di stasiun III. Perbedaan yang mencolok yakni pada tipe dasar dan kemiringan tepi danau. Kondisi stasiun III adalah berbatu-batu dan tepi danau curam dengan kedalaman air di atas $10 \mathrm{~m}$, sedangkan stasiun lain dasarnya berupa lumpur berpasir dengan kedalaman kurang dari $5 \mathrm{~m}$.

Di stasiun I dan IV dijumpai tanaman air dengan luas penutupan antara 42 sampai dengan $82 \%$ per meter persegi, sedangkan di stasiun lain (II dan III) tidak dijumpai tanaman air. Terdapat korelasi antara kelimpahan ikan dengan keberadaan tanaman air. Korelasi positif antara kelimpahan ikan $T$. celebensis dengan tanaman air ini dapat menjelaskan mengapa kelimpahan ikan lebih tinggi di stasiun I dan IV (Indiarto \& Nasution, 2004). Uji MannWhitney terhadap kelimpahan ikan di ke-2 stasiun (Tabel 1) tersebut juga menunjukkan bahwa kelimpahan ikan di ke-2 stasiun tidak berbeda nyata, baik pada ikan betina maupun jantan. Hal ini, memperkuat dugaan bahwa ada kaitan yang sangat erat antara kelimpahan ikan $T$. celebensis dengan keberadaan tanaman air.

Krebs (1985) mengatakan bahwa distribusi ikan dipengaruhi oleh tingkah laku ikan dalam memilih habitat dan hubungan antara ikan tersebut dengan organisme lain. Demikian pula, hal dengan ikan T. celebensis, pada umumnya memilih tempat di sekitar daerah dangkal yang banyak tanaman air sebagai tempat hidup.

Daerah dangkal dekat dengan tepi sampai dengan kedalaman $1 \mathrm{~m}$, merupakan tempat utama makrofita air yaitu Ottelia mesenterium (Whitten et al., 1987). Daerah dangkal ini sangat penting bagi sistem hayati perairan karena di samping berfungsi sebagai tempat pemijahan, juga berfungsi sebagai tempat berlindung bagi ikan, anak ikan dan jasad makanan ikan, serta menjaga kandungan oksigen dalam air melalui proses fotosintesis. Tanaman air sebagai produsen primer juga berperan penting dalam proses pemijahan ikan $T$. ladigesi (Axelrod \& Vonderwinkler, 1986) dan begitu juga dengan ikan rainbow Irian (Nasution, 2000). Selanjutnya, dikatakan bahwa telur ikan rainbow dijumpai di antara dedaunan tanaman air atau pada benda-benda seperti serabut di perairan dangkal. Kottelat (1991) mengatakan juga bahwa semua spesies Telmatherina yang diamati di lapangan atau di akuarium memijah dan menempelkan telur pada substrat.

\section{Distribusi Temporal}

Distribusi temporal ikan di masing-masing stasiun selama pengamatan dapat dilihat pada Gambar 3a dan 3b. Pada gambar tersebut terlihat kelimpahan ikan di stasiun III terendah dibandingkan stasiun lain. Bahkan pada bulan Mei ikan tidak tertangkap baik ikan jantan maupun betina, sedangkan pada bulan Nopember dan Pebruari hanya ikan jantan yang tertangkap. Diduga faktor kedalaman air (>10 m) dan tipe habitat bebatuan merupakan pembatas bagi ikan tersebut. Hal ini, menandakan juga bahwa stasiun tersebut bukan merupakan habitat yang ideal bagi ikan T. celebensis.

Jumlah ikan yang tertangkap pada bulan Nopember di stasiun I, II, dan IV cenderung meningkat. Peningkatan populasi ikan di stasiun tersebut diduga berkaitan dengan aktivitas reproduksi yang cenderung meningkat pada bulan tersebut (Gambar 4). Terjadi peningkatan populasi ikan ini disebabkan oleh kebutuhan ikan mencari tempat untuk memijah. Hal ini, merupakan salah satu faktor yang mendorong terjadi distribusi ikan ke tempat yang berbeda. Faktor penyebab perbedaan kelimpahan ikan musiman juga terjadi akibat ada perbedaan intensitas curah hujan. Hubungan antara kelimpahan ikan dengan curah hujan dapat dilihat pada Gambar 4. Kelimpahan ikan tertinggi terjadi pada bulan Nopember baik pada ikan jantan maupun ikan betina, sedangkan kelimpahan terendah terjadi pada bulan April. 


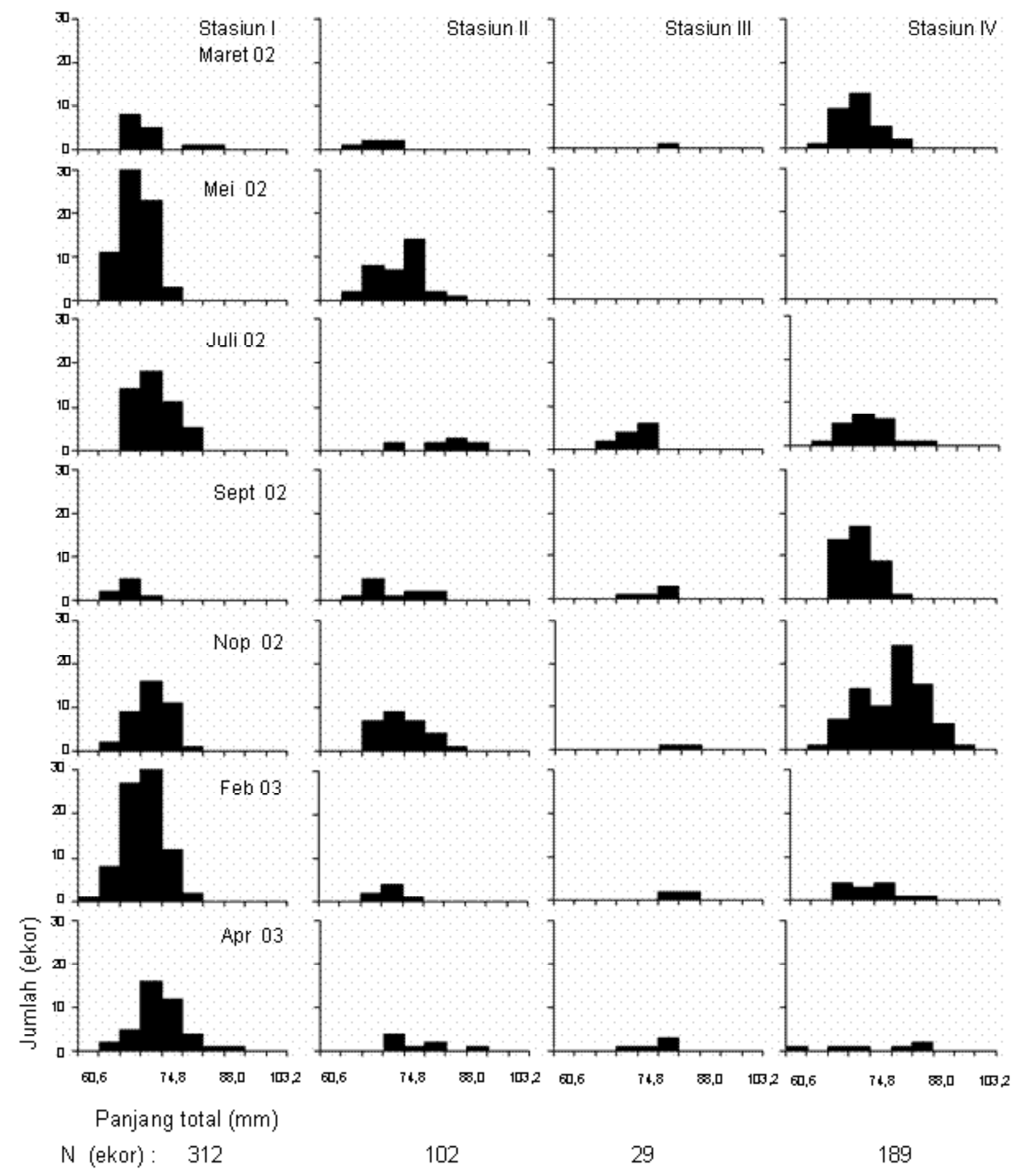

Gambar 3a. Hubungan antara kelimpahan dengan distribusi ukuran ikan T. celebensis jantan pada setiap stasiun dan waktu.

Figure 3a. Relationship between abundance and size distribution of male T. celebensis at each sampling station and time. 


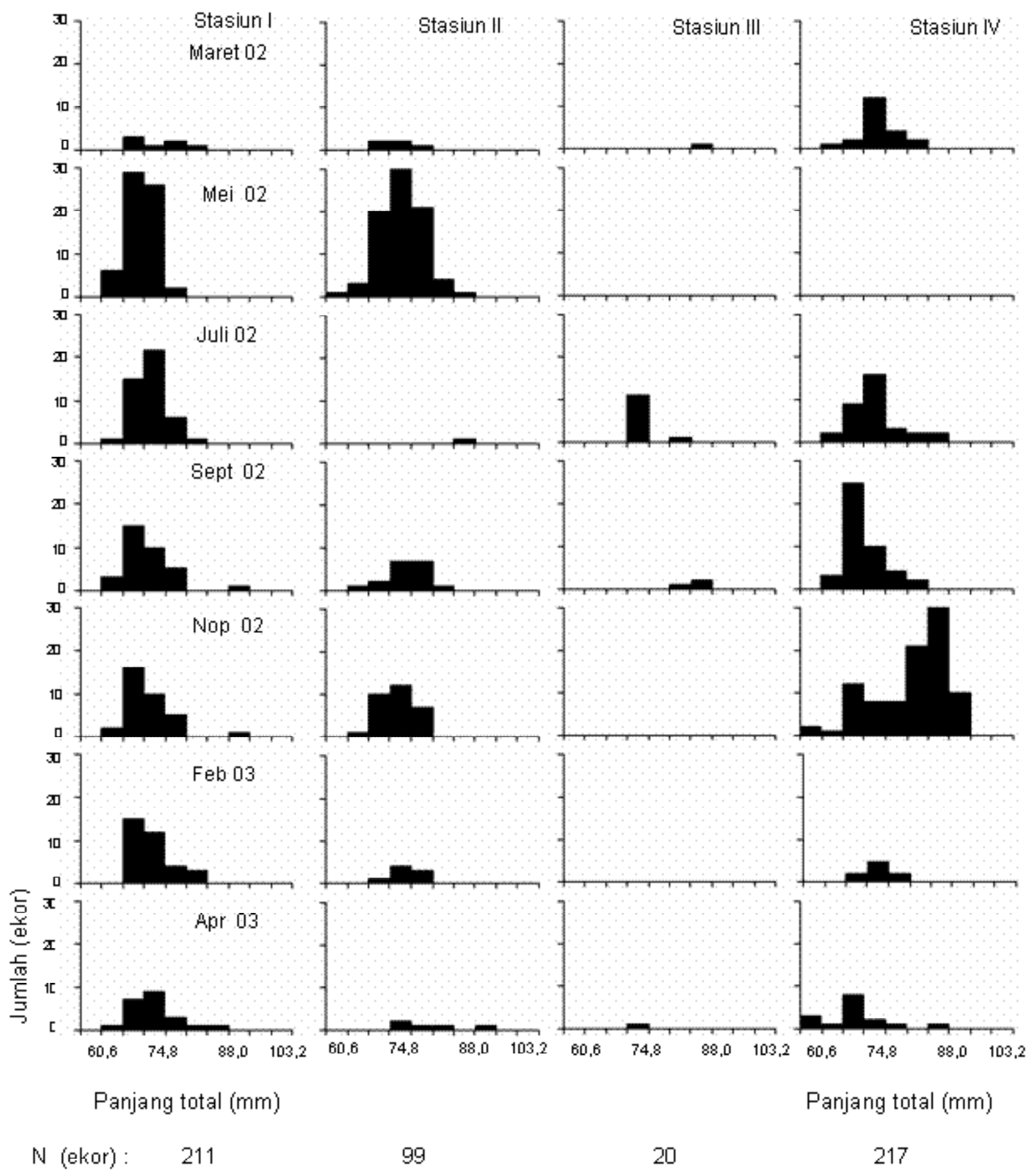

Gambar 3b. Hubungan antara kelimpahan dengan distribusi ukuran ikan T. celebensis betina pada setiap stasiun dan waktu.

Figure 3b. Relationship between abundance and size distribution of female T. celebensis at each sampling station and time. 


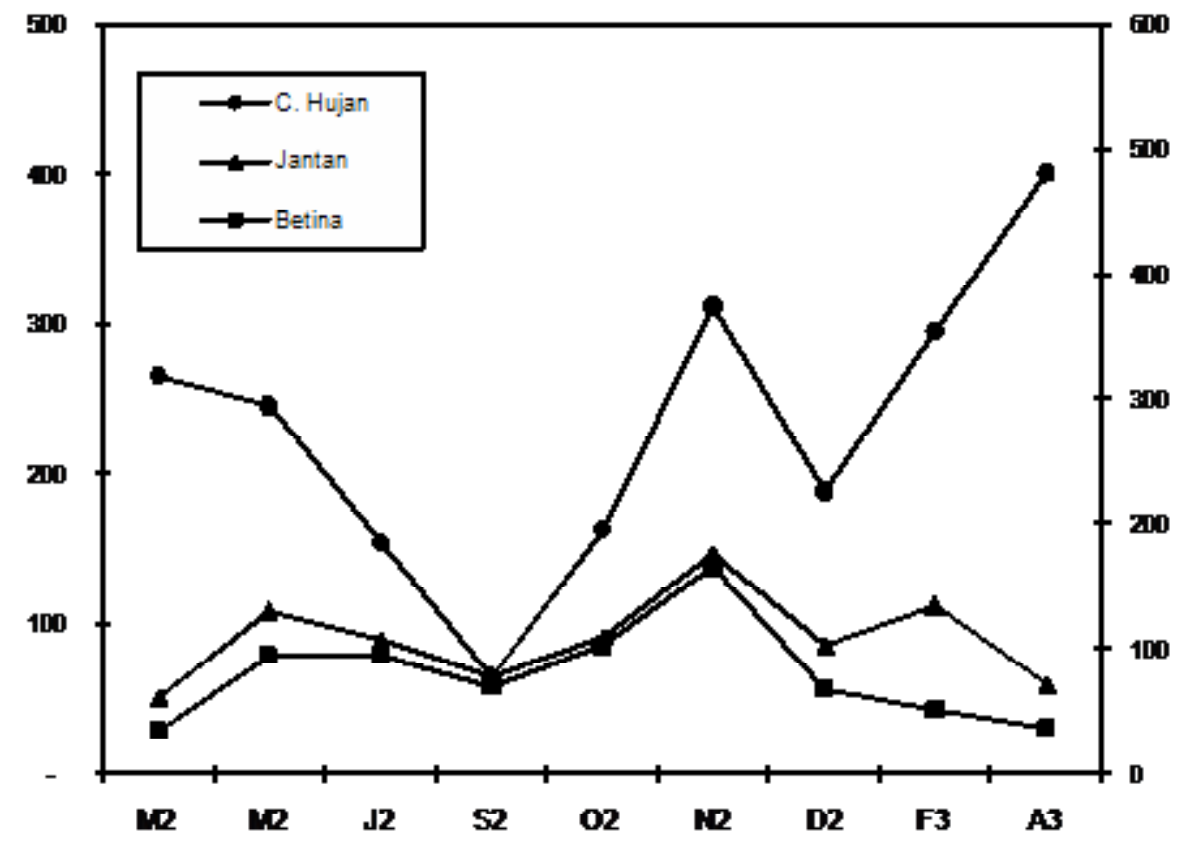

Gambar 4. Hubungan antara curah hujan dengan distribusi kelimpahan ikan T. celebensis.

Keterangan: M2: Maret, M2: Mei, J2: Juli, S2: September, O2: Oktober, N2: Nopember, D2: Desember 2002, F3: Pebruari, dan A3: April 2003.

Figure 4. Relationship between rainfall and abundance distribution of T. celebensis.

Remaks: $\quad$ M2: March, M2: May, J2: July, S2: September, O2: October, N2: November, D2: December 2002, F3: February, and A3: April 2003.

Curah hujan terendah di Danau Towuti yang terjadi pada bulan September mengakibatkan tinggi permukaan air danau berkurang (26,63 menjadi 26,20 m) (Tabel 2). Penurunan ketinggian air mengakibatkan lahan habitat ikan berkurang, sedangkan pada bulan Oktober curah hujan mulai meningkat, namun ketinggian air rendah yaitu
25,14 m. Pada bulan Nopember sampai dengan April curah hujan meningkat dan ketinggian air mulai bertambah 24,73 menjadi $26,15 \mathrm{~m}$. Daerah yang semula mengering mulai terendam kembali dan populasi ikan $T$. celebensis mulai meningkat dan mencapai puncak pada bulan Nopember.

Tabel2. Tinggi muka air di Danau Towuti dari bulan Maret 2002 sampai dengan April 2003

Table 2. Water level in Lake Towuti from March 2002 until April 2003

\begin{tabular}{lcclcc}
\hline $\begin{array}{c}\text { Bulan/ } \\
\text { Month }\end{array}$ & $\begin{array}{c}\text { Tahun/ } \\
\text { Year }\end{array}$ & $\begin{array}{c}\text { Tinggi muka air/ } \\
\text { Water level }(\mathbf{m})\end{array}$ & $\begin{array}{c}\text { Bulan/ } \\
\text { Month }\end{array}$ & $\begin{array}{c}\text { Tahun/ } \\
\text { Year }\end{array}$ & $\begin{array}{c}\text { Tinggi muka air/ } \\
\text { Water level }(\mathbf{m})\end{array}$ \\
\hline Maret & 2002 & 25,25 & Oktober & 2002 & 25,14 \\
April & 2002 & 26,15 & Nopember & 2002 & 24,73 \\
Mei & 2002 & 26,63 & Desember & 2002 & 25,12 \\
Juni & 2002 & 26,39 & Januari & 2003 & 25,28 \\
Juli & 2002 & 26,30 & Pebruari & 2003 & 25,56 \\
Agustus & 2002 & 26,24 & Maret & 2003 & 25,70 \\
September & 2002 & 26,20 & April & 2003 & 26,15 \\
\hline
\end{tabular}


Penambahan ketinggian muka air danau menambah luas genangan dan memperluas daerah ikan mencari makan (feeding ground). Menurut Furkon (2003) makanan yang ditemukan dalam lambung ikan ini terdiri atas 4 kelompok yaitu insekta, diatom, desmid, dan serasah. Komposisi jenis makanan didominasi oleh jenis insekta Ochtera humilis. Organisme ini merupakan makanan utama ikan tersebut dan makanan tambahan adalah potongan insekta lain dan serasah. Hal ini, memperlihatkan ada keterkaitan antara jenis makanan (insekta dan serasah) yang terdapat di lambung ikan dengan habitat ikan $T$. celebensis. Daerah yang banyak terdapat tanaman air merupakan tempat berkembang biak insekta air.
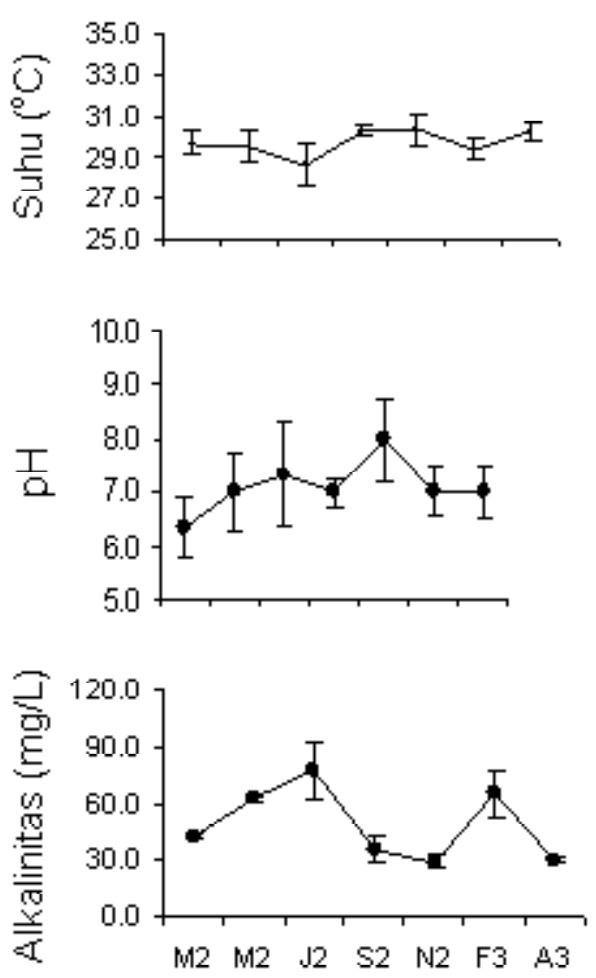

Berdasarkan pada analisis regresi berganda terhadap hubungan antara kualitas air dan kelimpahan ikan secara temporal, didapatkan bahwa parameter yang memiliki nilai korelasi Pearson yang tinggi secara berurutan adalah parameter oksigen terlarut/DO $(0,59), \mathrm{pH}(0,53)$, turbiditas $(0,29)$, suhu $(0,27)$, dan alkalinitas $(-0,22)$. Peningkatan kualitas air yang dicerminkan oleh parameter oksigen terlarut dan $\mathrm{pH}$, mendorong peningkatan kelimpahan ikan. Hal ini, dapat dilihat dari ada peningkatan kelimpahan dan keragaman ukuran ikan yang tertangkap seperti pada stasiun I dan IV. Keragaman ukuran ikan yang tertangkap dapat dijadikan petunjuk bahwa ada proses regenerasi ikan. Fluktuasi kualitas air selama pengamatan dapat dilihat pada Gambar 5.

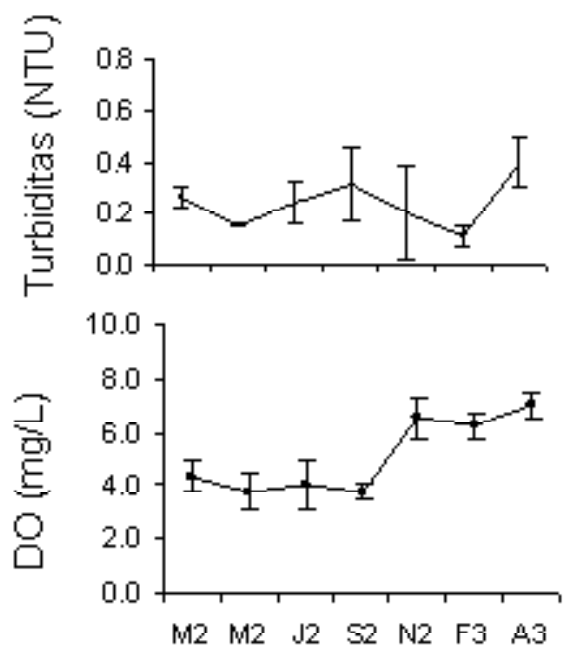

Bulan

\section{Bulan}

Gambar 5. Kualitas air (suhu, turbiditas, $\mathrm{pH}, \mathrm{DO}$, dan alkalinitas).

Keterangan: M2: Maret, M2: Mei, J2: Juli, S2: September, O2: Oktober, N2: Nopember, D2: Desember 2002, F3: Pebruari, A3: April 2003.

Figure 5. Water quality (temperature, turbidity, $\mathrm{pH}, \mathrm{DO}$, and alkalinity).

Remarks: M2: March, M2: May, J2: July, S2: September, O2: October, N2: November, D2: December 2002, F3: February, A3: April 2003. 
Kandungan oksigen terlarut berdasarkan pada ambang toleransi baku mutu kualitas air menurut Anonim (2001) adalah minimum $3 \mathrm{mg}$ per L, sedangkan untuk parameter suhu fluktuasi tidak melebihi $3^{\circ} \mathrm{C}$, dan $\mathrm{pH}: 6$ sampai dengan 9 . Kisaran nilai masing-masing parameter kualitas air tersebut dalam ambang batas untuk perikanan.

\section{KESIMPULAN DAN SARAN}

1. Ikan T. celebensis menyebar di setiap stasiun (I, II, III, dan IV) mulai dari wilayah tepian (litoral) sampai dengan ke tengah danau yaitu di Pulau Loeha. Penyebaran ikan secara spasial lebih dipengaruhi oleh tipe habitat. Di daerah yang terdapat tanaman air dengan kedalaman air 1 sampai dengan $3 \mathrm{~m}$, kelimpahan ikan relatif lebih tinggi dibandingkan di stasiun yang tidak terdapat tanaman air. Secara temporal, distribusi ikan dipengaruhi oleh ketinggian air, oksigen terlarut, dan $\mathrm{pH}$. Kelimpahan ikan tertinggi terdapat pada bulan Nopember.

2. Untuk merumuskan kebijaksanan pengelolaan dalam upaya konservasi, disarankan penangkapan ikan ini dibatasi pada bulan Nopember, di stasiun yang terdapat tanaman air dan relatif dangkal.

\section{PERSANTUNAN}

Kegiatan dari hasil riset ecological distribution of endemic fish species in lakes Poso and Malili Complex, Sulawesi Island, T.A. 2003-2004, di Asean Regional Centre for Biodiversity Conservation and the European Comission.

\section{DAFTAR PUSTAKA}

Anonim. 2001. Peraturan pemerintah Republik Indonesia No.82 tahun 2001 tentang pengelolaan kualitas air dan pengendalian pencemaran air. Jakarta. $38 \mathrm{hal}$.

APHA-AWWA-WEF. 1998. Standard methods for the examination of water and waste water. $20^{\text {th }}$ Edition. Washington.

Axelrod, H. R. \& W. Vonderwinkler. 1986. Encyclopedia of tropical fishes. T. F. H.Publication. Inc. Canada. $521 \mathrm{p}$.

Bhukaswan, T. 1980. Management of asian reservoir fisheries. FAO Fish. Technical paper 207:69.
Furkon, A. 2003. Kebiasaan makanan dan pertumbuhan ikan opudi Telmatherina celebensis di Danau Towuti, Sulawesi Selatan. Fakultas Perikanan dan IImu Kelautan. Institut Pertanian Bogor. Bogor. 41 hal.

Haffner, G. D., P. E. Hehanussa, \& D. I. Hartoto. 2001. The biology and physical processes of large lakes of Indonesia: Lakes Matano and Towuti. In M. Munawar \& R. E. Hecky (eds.). The Great Lakes of The World (GLOW): Food-web, health, and integrity, Netherlands. p 183-192.

Indiarto, Y. \& S. H. Nasution. 2004. Makrofita air Ottelia mesenterium dalam kaitannya dengan kelimpahan ikan Rainbow Selebensis (Telmatherina celebensis) di Danau Towuti. LIMNOTEK Perairan Darat Tropis di Indonesia. XI (2): 45-49.

Kottelat, M. 1991. Sailfin silversides (Pisces: Telmatherinidae) of Lake Matano, Sulawesi, Indonesia, with description of six new species. Ichthyol. Explorer. Freshwaters. 1: 321-344.

Kottelat, M., A. J. Whitten, S. N. Kartikasari, \& S. Wirjoatmodjo. 1993. Ikan air tawar Indonesia bagian barat dan Sulawesi. Periplus Edition (HK) Ltd. Bekerjasama dengan Proyek EMDI. Kantor Menteri Negara Kependudukan dan Lingkungan Hidup Republik Indonesia. Jakarta. 293 hal.

Krebs, C. J. 1985. Ecology, the experimental analysis of distribution and abundance. 3 rd edition. Harper and Row Publisher. New York. 694 p.

Nasution, S. H. 2000. Ikan hias air tawar rainbow. Cetakan I. Penebar Swadaya. Jakarta. 96 hal.

Steel, R. G. D. \& J. H. Torrie. 1981. Principles and procedure of statistic. Second edition. Mic Graw Hill Book Company. Inc New York. 748 p.

Whitten, A. J., M. Mustafa, \& G. S. Henderson. 1987. The ecology of Sulawesi. Gajah Mada University Press. $777 \mathrm{p}$.

Wirjoatmodjo, S., Sulistiono, M. F. Rahardjo, I. S. Suwelo, \& R. K. Hadiyati. 2003. Ecological distribution of endemic fish species in Lakes Poso and Malili Complex, Sulawesi Island. Funded by Asean Regional Centre for Biodiversity Conservation and the European Comission. $30 \mathrm{p}$. 